\title{
Agronomical evaluation of six soybean cultivars using correlation and regression analysis under different irrigation regime conditions
}

\author{
Ashraf A. Abd El-Mohsen*, Gamalat O. Mahmoud and Sayed A. Safina \\ Department of Agronomy, Faculty of Agriculture, Cairo University, El-Gamaa Street, P. O. Box 12613 Giza, Egypt. \\ Accepted 20 March, 2013
}

\begin{abstract}
Two field experiments were conducted during summer seasons of 2011 and 2012 to study the effect of irrigation regimes at different growth stages on seed, oil and protein yields of soybean cultivars. The interrelationships among seed yield $\mathrm{ha}^{-1}$ and its attributes through simple correlation and stepwise regression analysis were evaluated. The results indicated that the percentages of oil and protein in the seeds were significantly affected by water regimes and caused a decrease in oil percentage and increase in protein percentage. In addition, both oil and protein output per unit area was significantly reduced, as water regimes increased. The results showed that skipping irrigation during vegetative, flowering and pod filling stages had no effect on economic yield and save $14 \%$ from total irrigation costs of soybean production, but skipping two or three irrigations during vegetative, flowering and pod filling stages had effect on economic yield of soybean production under the environmental conditions of Giza region. Results revealed that Giza 111 proved to be the best cultivar followed by Giza 21 among the six cultivars included in the test under different water regime. Simple correlation analysis indicated that seed yield ha ${ }^{-1}$ was positively correlated with number of branches plant ${ }^{-1}$, number of pods plant ${ }^{-1}$, 1000 -seed weight and seed yield plant $^{-1}$. Stepwise regression procedure indicated that number of branches plant ${ }^{-1}$, number of pods plant ${ }^{-1}$ and number of seeds pod $^{-1}$, were the most important characters affecting seed yield $\mathrm{ha}^{-1}$. Combined analysis of variance (ANOVA) showed that effect of irrigation regimes, cultivars and irrigation regimes $\times$ cultivars on seed, oil and protein yield were significant.
\end{abstract}

Key words: Soybean, skipping irrigations, cultivars, seed yield, oil yield, protein yield, correlation, regression.

\section{INTRODUCTION}

Soybean (Glycine max L.) is considered to be one of the most important oil seeds in the world. It can provide oils and vegetable protein suitable for feeding humans as well as animals. Soybean is the most important oil crop of world which contains about 18 to $22 \%$ cholesterol free oil with $85 \%$ unsaturated fatty acids and 38 to $42 \%$ protein (Ali et al., 2009). It has the potential to bridge the gap between the demand and supply of edible oil and protein.
In Egypt, it is grown on an area of 15233000 ha and its production is 43342000 tons with an average seed yield of 2.84 tons ha ${ }^{-1}$ (FAO, 2010). Water shortage is one of the main constraints for economic development. Egypt has a definite amount of water that can be used for irrigation. Due to rapid population growth, increasing food requirement and limited water resources, deficit irrigation is inevitable. 
Table 1. Meteorological data for the study period in 2011 and 2012 at Giza Governorate*.

\begin{tabular}{lcccccc}
\hline \multirow{2}{*}{ Month } & \multicolumn{2}{c}{ Mean monthly temperature $\left({ }^{\circ} \mathbf{C}\right)$} & \multicolumn{2}{c}{ Mean relative humidity (\%) } & \multicolumn{2}{c}{ Precipitation (mm) } \\
\cline { 2 - 6 } & $\mathbf{2 0 1 1}$ & $\mathbf{2 0 1 2}$ & $\mathbf{2 0 1 1}$ & $\mathbf{2 0 1 2}$ & $\mathbf{2 0 1 1}$ & $\mathbf{2 0 1 2}$ \\
\hline May & 24.80 & 26.30 & 47.00 & 46.00 & 0.00 & 0.00 \\
June & 27.50 & 29.40 & 52.00 & 50.00 & 0.00 & 0.00 \\
July & 29.40 & 30.50 & 57.00 & 56.00 & 0.00 & 0.00 \\
August & 29.10 & 30.40 & 58.00 & 54.00 & 0.00 & 0.00 \\
September & 27.80 & 27.70 & 59.00 & 57.00 & 0.00 & 0.00 \\
\hline
\end{tabular}

*Data obtained from the Central Laboratory for Agriculture Climate (CLAC), A.R.C. Egypt.

Therefore, decreasing plant water consumption by using more efficient irrigation methods, plant breeding technology, longer irrigation intervals, higher moisture depletion, skipping irrigation during the early vegetative growth or during maturation stage and timing the length of irrigation interval with the stage of plant growth. This will save irrigation through reducing number of irrigation but still attain similar economic yield. Therefore, any procedure that can maximize the use of water in agriculture is of extreme importance to the security and economic welfare of Egypt.

The yield of soybean is a function of many factors among the cultivars and irrigation being the most important ones (Kobraee et al., 2011). Among the package of production technology of soybean, irrigation management plays an important role because water has direct relationship with crop yield. Drought stress or drought badly affects the yield of different crops. It has been suggested that in many crops differences in sensitivity to drought stress occur at different growth stages (Abayomi, 2008). Therefore, knowledge on the irrigation schedule of soybean under deficit irrigation condition becomes more important. This is because all field crops respond differently in different phenological stages to changing water status of the soil under deficit irrigation, which means that plants are more sensitive to water deficit at some stages than at other stages (Kirda, 2002). The most important times for soybean plants to have adequate water are during pod development and seed fill (Kranz et al., 1998). These are the stages when water stress can lead to a significant decrease in yield.

In soybean, seed yield, as in other crops, is a complex character, which is dependent on a number of variables. Thus, to make effective selection for high seed yield a thorough understanding of yield contributing characters and their interrelationships among themselves and with yield is necessary. Therefore, knowledge of relationship between yield and its components obtainable through correlation and regression analysis helps a great deal to formulate selection (Salimi and Moradi, 2012). Correlation coefficient ( $r$ ), measures only the degree (intensity) and nature (direction) of association between characters. Regression coefficient (b), quantifies the rate of change in dependent variable for unit change in the independent variable. Stepwise regression analysis is used to determine the percentage contribution of more important traits that had significant association with seed yield (Golkar et al., 2011). With considering that selection is one of the important tools in soybean improvement, it is important to realize the relative importance of traits in influencing the seed yield in a desired direction.

Keeping in view all these aspects, the objectives of this study was to investigate effects of eight different irrigation regimes on yield and quality traits of six soybean cultivars at different growth stages under Middle Egypt conditions at Giza Governorate. Also to determine relationship between yield and yield components by using different statistical methods to help soybean breeders how to determine the effect of yield components and what yield components could be efficiently used in breeding program.

\section{MATERIALS AND METHODS}

\section{Experimental site and conditions}

The present study was conducted during the 2011 and 2012 summer seasons at the Experimental Farm of the Faculty of Agriculture at Cairo University, Giza, Egypt. Experiment location was $22.50 \mathrm{~m}$ above sea level and it was situated within $30^{\circ}, 02^{\prime} \mathrm{N}$ latitude and $31^{\circ}, 13^{\prime} \mathrm{E}$ longitude. Soil samples $(0$ to $30 \mathrm{~cm})$ were taken at sowing and analyzed for some parameters. The soil was a clay loam with $0.91 \%$ organic matter content, an electrical conductivity (EC) of $0.29 \mathrm{ds} \mathrm{m}^{-1}$ and a pH of 7.80 . Total nitrogen (N) content was $0.46 \%$, available phosphorus $(P)$ was $4.81 \mathrm{mg} \mathrm{kg}$ , available potassium (K) was $84.00 \mathrm{mg} \mathrm{kg}^{-1}, \mathrm{SO}_{4}-\mathrm{N}$ was $2.33 \mathrm{mg}$ $\mathrm{kg}^{-1}$ and no salinity problems were observed. The experimental area has an arid climate with hot dry summers and cool winters. The meteorological data during the study are shown in Table 1.

\section{Experimental material}

The experimental material used in the present study comprised of 6 soybean cultivars viz., Giza 21, Giza 35, Giza 82, Giza 83, Giza 111 and Crawford differing for the characters studied. The descriptions of those cultivars are presented in Table 2. The cultivars Giza 21, Giza 35 and Giza 111 are characterized for improved quality, and are insect-resistance and need low amount of nitrogenous fertilizer. The seed of cultivars was obtained from Food Legumes Research Section, Agricultural Research Center, 
Table 2. The descriptions of soybean cultivars used in this study.

\begin{tabular}{llcll}
\hline Cultivar & Country origin & Maturity group & Growth habit & Pedigree \\
\hline Giza 21 & Egypt & IV & Indeterminate & Crawford $\times$ Celest \\
Giza 35 & Egypt & III & Indeterminate & Crawford $\times$ Celest \\
Giza 82 & Egypt & II & Indeterminate & Crawford $\times$ Maplepresto \\
Giza 83 & Egypt & II & Indeterminate & Union $\times$ L76-0038 \\
Giza 111 & Egypt & IV & Indeterminate & Crawford $\times$ Celest \\
Crawford & USA & IV & Indeterminate & Williams $\times$ Columbus \\
\hline
\end{tabular}

Table 3. Definition of experimental treatments of water regimes.

\begin{tabular}{clccc}
\hline $\begin{array}{l}\text { Irrigation } \\
\text { treatment }\end{array}$ & $\begin{array}{l}\text { Description of irrigation regimes } \\
\text { (skip timing) }\end{array}$ & $\begin{array}{c}\text { No. of irrigations } \\
\text { received }\end{array}$ & $\begin{array}{c}\text { No. of skipping } \\
\text { irrigations }\end{array}$ & $\begin{array}{c}\text { Saving in irrigation } \\
\text { water (\%) }\end{array}$ \\
\hline$I_{1}$ & Normal irrigation at all growth stages (control) & 7 & 0 & 0 \\
$I_{2}$ & Skipping irrigation at vegetative stage & 6 & 1 & 14 \\
$I_{3}$ & Skipping irrigation at flowering stage & 6 & 1 & 14 \\
$I_{4}$ & Skipping irrigation at pod filling stage & 6 & 1 & 14 \\
$I_{5}$ & Skipping irrigation at vegetative and flowering stage & 5 & 2 & 28 \\
$I_{6}$ & Skipping irrigation at vegetative and pod filling stage & 5 & 2 & 28 \\
$I_{7}$ & Skipping irrigation at flowering and pod filling stage & 5 & 2 & 28 \\
$I_{8}$ & Skipping irrigation at vegetative, flowering and pod & 4 & 3 & 42 \\
\hline
\end{tabular}

Giza, Egypt.

\section{Experimental design and treatments}

The experiments were laid-out in a strip-plot design with three replications. The vertical plots were chosen for water regime and the horizontal plots were devoted for six soybean cultivars. The experimental plots consisted of four rows; each was $3 \mathrm{~m}$ long and $0.6 \mathrm{~m}$ width occupying an area of $7.2 \mathrm{~m}^{2}$. The plots were isolated by ditches of $1.5 \mathrm{~m}$ in width to avoid lateral movement of irrigation water to adjacent plots. The irrigation system adopted in these experiments was surface irrigation. The amounts of irrigation water, which applied for soybean plants during growth season are about $6863 \mathrm{~m}^{3} / \mathrm{ha}$ and water resource, are from the River Nile. Life irrigation or first irrigation was started after 21 days from planting then irrigation intervals were each 15 days. The crop during grown seasons received seven irrigations (control) including planting irrigation. Water regime treatments were applied by skipping one, two and three irrigations at three critical stages: vegetative, flowering and pod filling stages. Eight treatments were defined by different combinations of irrigation at three different growth stages. For this purpose, the life cycle of soybean was divided into three stages, namely vegetative, flowering, and pod filling. According to the classification of developmental stages of soybean (Fehr et al., 1971), the vegetative stage corresponded to the duration from the $V_{1}$ stage (that is, just after germination) to the beginning of $R_{1}$ stage. The flowering stage was defined as the period between the observation of first flower $\left(R_{1}\right.$ stage $)$ and $75 \%$ pod initiation $\left(R_{4}\right.$ stage). The period from $75 \%$ pod initiation $\left(R_{4}\right)$ to maturity $\left(R_{8}\right)$ was defined as the pod filling stage. Irrigation regimes included eight treatments (Table 3).

\section{Cultural practices}

The two season experiments were sown on 10 and $12^{\text {th }}$ of May for 2011 and 2012 seasons, respectively. Soybean seeds were planted in hill spaced $20 \mathrm{~cm}$ on the two sides of the ridge, producing 333,333 plants ha $^{-1}$. Each hill received 4 seeds and was thinned to two plants per hill 21 days after sowing. Seedlings were thinned at 21 days after sowing to secure two plants hill ${ }^{-1}$. The plots were irrigated using a furrow irrigation method and subsequent irrigations were applied every 15 days during plant development, up to 3 weeks before final harvest. Seeds were pretreated with Rhizobium japonicum and weed control was done manually. Before planting, $200 \mathrm{~kg}$ calcium superphosphate $\left(15.5 \% \mathrm{P}_{2} \mathrm{O}_{5}\right)$ per hectare was applied during seed bed preparation. Potassium sulfate $(75 \mathrm{~kg}$ $\mathrm{ha}^{-1}, 48 \% \mathrm{~K}_{2} \mathrm{O}$ ) was applied at 21 days after planting. Nitrogen fertilizer in the form of Urea $(46 \% \mathrm{~N})$ was added at the rate of $90 \mathrm{~kg}$ $\mathrm{N} \mathrm{ha-1}{ }^{-1}$ was divided into two equal doses prior to the first and second irrigations. All cultural operations were kept normal and uniform except water regime levels.

\section{Data collection}

At maturity, to avoid marginal effects, two rows (one row from each side) and $1 \mathrm{~m}$ from the top and bottom ends of each plot were discarded. Ten guarded plants were randomly sampled from each plot and the following traits were measured; plant height $(\mathrm{cm})$, number of branches plant ${ }^{-1}$, number of pods plant ${ }^{-1}$, number of seeds pod $^{-1}$ and seed yield plant ${ }^{-1}(\mathrm{~g})$. Seed yield kg plot ${ }^{-1}$ was calculated over all plants in the plot. Seed index and yield per hectare were determined on plot basis.

Seed oil content was determined using Soxhlet apparatus and 
Table 4. Combined ANOVA (F-value and level of significance) of the effect of year, irrigation regime, cultivar and their interactions for seed, oil, protein yields and quality traits across 2 years (2011 and 2012).

\begin{tabular}{|c|c|c|c|c|c|c|}
\hline \multirow[b]{2}{*}{ Source of variation } & \multirow[b]{2}{*}{ df } & \multicolumn{5}{|c|}{ F-value and level of significance } \\
\hline & & $\begin{array}{l}\text { Seed yield } \\
\left(\mathrm{kg} \mathrm{ha}^{-1}\right)\end{array}$ & $\begin{array}{l}\text { Seed oil content } \\
(\%)\end{array}$ & $\begin{array}{l}\text { Oil yield } \\
\left(\mathrm{kg} \mathrm{ha}^{-1}\right)\end{array}$ & $\begin{array}{c}\text { Seed protein content } \\
(\%)\end{array}$ & $\begin{array}{l}\text { Protein yield } \\
\left(\mathrm{kg} \mathrm{ha}^{-1}\right)\end{array}$ \\
\hline Years (Y) & 1 & $10.12^{*}$ & NS & $17.42^{*}$ & NS & $9.53^{\star}$ \\
\hline Rep/Years & 4 & $9.45^{* *}$ & NS & $11.49^{* *}$ & NS & $12.19^{\star *}$ \\
\hline Irrigation regimes (I) & 7 & $36.54^{\star *}$ & $8.14^{*}$ & $23.65^{* *}$ & $5.42^{*}$ & $19.71^{* *}$ \\
\hline$I \times Y$ & 7 & NS & NS & NS & NS & NS \\
\hline Cultivars (C) & 5 & $12.45^{\star \star}$ & $5.11^{*}$ & $6.29^{*}$ & $8.21^{* *}$ & $4.24^{*}$ \\
\hline $\mathrm{C} \times \mathrm{Y}$ & 5 & $6.52^{*}$ & NS & $7.24^{*}$ & NS & $4.55^{\star}$ \\
\hline $\mathrm{I} \times \mathrm{C}$ & 35 & $34.00^{* *}$ & NS & $22.53^{\star *}$ & NS & $24.98^{\star \star}$ \\
\hline $\mathrm{I} \times \mathrm{C} \times \mathrm{Y}$ & 35 & NS & NS & NS & NS & NS \\
\hline
\end{tabular}

*Significant at $P<0.05 ;{ }^{* *}$ Significant at $P<0.01$; NS $=$ non-significant.

diethyl ether as a solvent and protein percentage of seeds was measured using Kjeldahl method according to AOAC (2000). Protein yield $\left(\mathrm{kg} \mathrm{ha}^{-1}\right)$ and oil yield $\left(\mathrm{kg} \mathrm{ha}^{-1}\right)$ were calculated by multiplying seed yield $\left(\mathrm{kg} \mathrm{ha}^{-1}\right)$ by protein and oil percentage, respectively.

\section{Statistical analyses}

The statistical analysis of the data on individual character was carried out on the mean values over three replications. The statistical methods adopted are as follows.

Collected data were subjected to the proper of statistical analysis of variance (ANOVA) of strip plot design as mentioned by Gomez and Gomez (1984). Data were tested for violation of assumptions underlying the ANOVA. Data for the 2 years was tested for homogeneity using Bartlett's (1937) test of homogeneity and it was found to be homogeneous so the data were combined for analysis. The combined ANOVA was carried out according to Steel et al. (1997), to estimate the main effects of the different sources of variation and their interactions. Duncan's multiple range test (1955) was applied to detect statistical differences among irrigation and cultivar treatment means, when the F-test for these treatments was significant at $5 \%$ probability level.

Data over both seasons of seed yield ha ${ }^{-1}$ and its attributes were subjected to simple correlation coefficients and simple linear regression analysis according to Sendecor and Cochran (1989) to construct the prediction model for seed, oil and protein yield of soybean was performed. Stepwise multiple linear regression analysis was done as applied by Draper and Smith (1998) to determine the best variables accounted for most variance in seed yield. The relative contribution was calculated as coefficient of determination $\left(R^{2}\right)$. Finally, statistical evaluation was carried out by using the computer statistical package program, MSTAT-C Version 2.1 (Russell, 1994) and Statistical Package for Social Science, version 17 (SPSS, 2008).

\section{RESULTS AND DISCUSSION}

\section{Effect of irrigation regimes}

A summary of the statistical analyses of soybean seed, oil and protein yield, oil and protein contents are given in
Table 4. The results of the combined ANOVA, after homogeneity test for error variances, are summarized in Table 4. The combined ANOVA averaged across 2 years (Table 4) showed significant differences $(P \leq 0.01)$, among irrigation regimes and the soybean cultivars for all the traits measured, suggesting that irrigation regime and cultivar differences were major sources of the variability of these constituent.

\section{Performance of agronomic parameters}

Irrigation regimes are one of the most important methods of management of irrigation to save irrigation water without much damage to plants. The ANOVA combined over years showed significant differences among treatment means for seed, oil and protein yields (Table $4)$.

\section{Seed yield $\left(\mathrm{kg} \mathrm{ha}^{-1}\right)$}

Seed yield is the combined function of different components and it is a complex character depending upon a large number of environmental, morphological and physiological characters. It can be seen based on ANOVA that the seed yield of soybean was significantly affected by water regime treatments (Table 4).

The eight irrigation regimes differed in their effect on soybean seed yield $\left(\mathrm{kg} \mathrm{ha}^{-1}\right)$. Averaged across years, the highest seed yield (3423.6 kg ha-1) was observed for the $\mathrm{I}_{3}$ treatment (6 irrigations till harvest), where skipping one irrigation at flowering stage, while the lowest yield $\left(2030.6 \mathrm{~kg} \mathrm{ha}^{-1}\right.$ ) was for the $\mathrm{I}_{8}$ treatment (4 irrigations till harvest), where skipping three irrigations at vegetative, flowering and pod filling (Table 5). The highest seed yield $\left(3423.6 \mathrm{~kg} \mathrm{ha}^{-1}\right)$ was produced in $\mathrm{I}_{3}$ treatment, which was $13.52 \%$ higher than that of control treatment (seven 
Table 5. Effect of skipping irrigation on seed, oil and protein yield and quality traits of soybean.

\begin{tabular}{cccccc}
\hline $\begin{array}{c}\text { Irrigation } \\
\text { treatment }\end{array}$ & $\begin{array}{c}\text { Seed yield } \\
\left(\mathbf{k g ~ h a}^{-1}\right)\end{array}$ & $\begin{array}{c}\text { Oil content } \\
(\%)\end{array}$ & $\begin{array}{c}\text { Protein content } \\
(\%)\end{array}$ & $\begin{array}{c}\text { Oil yield } \\
\left(\mathbf{k g ~ h a}^{-1}\right)\end{array}$ & $\begin{array}{c}\text { Protein yield } \\
\left(\mathbf{k g ~ h}^{-1}\right)\end{array}$ \\
\hline $\mathrm{I}_{1}$ & $3015.8^{\mathrm{bc}}$ & $21.50^{\mathrm{a}}$ & $37.24^{\mathrm{e}}$ & $570.63^{\mathrm{d}}$ & $1170.40^{\mathrm{c}}$ \\
$\mathrm{I}_{2}$ & $3381.4^{\mathrm{a}}$ & $20.53^{\mathrm{a}}$ & $39.22^{\mathrm{d}}$ & $645.00^{\mathrm{ab}}$ & $1326.18^{\mathrm{a}}$ \\
$\mathrm{I}_{3}$ & $3423.6^{\mathrm{a}}$ & $20.20^{\mathrm{a}}$ & $39.69^{\mathrm{d}}$ & $685.85^{\mathrm{a}}$ & $1358.82^{\mathrm{a}}$ \\
$\mathrm{I}_{4}$ & $3092.7^{\mathrm{b}}$ & $20.00^{\mathrm{a}}$ & $39.61^{\mathrm{d}}$ & $634.80^{\mathrm{ab}}$ & $1225.01^{\mathrm{a}}$ \\
$\mathrm{I}_{5}$ & $2677.7^{\mathrm{d}}$ & $19.83^{\mathrm{a}}$ & $40.36^{\mathrm{bc}}$ & $564.24^{\mathrm{bcd}}$ & $1080.71^{\mathrm{b}}$ \\
$\mathrm{I}_{6}$ & $2636.2^{\mathrm{d}}$ & $19.55^{\mathrm{a}}$ & $40.57^{\mathrm{ab}}$ & $518.36^{\mathrm{cd}}$ & $1069.50^{\mathrm{b}}$ \\
$\mathrm{I}_{7}$ & $2864.7^{\mathrm{bc}}$ & $19.32^{\mathrm{b}}$ & $40.71^{\mathrm{a}}$ & $549.49^{\mathrm{cd}}$ & $1066.21^{\mathrm{b}}$ \\
$\mathrm{I}_{8}$ & $2030.6^{\mathrm{e}}$ & $17.07^{\mathrm{c}}$ & $41.15^{\mathrm{a}}$ & $404.26^{\mathrm{e}}$ & $835.59^{\mathrm{d}}$ \\
\hline
\end{tabular}

Means followed by common letter(s) are not significantly different from each other according to Duncan's multiple range test (DMRT). $I_{1}=7$ irrigation (Control), $I_{2}=6$ irrigations (skipping one irrigation at vegetative stage), $l_{3}=6$ irrigations (skipping one irrigation at flowering stage), $I_{4}=6$ irrigations (skipping one irrigation at pod filling), $I_{5}=5$ irrigations (skipping two irrigations at vegetative and flowering stages), $I_{6}=5$ irrigations (skipping two irrigations at vegetative and pod filling stages), $I_{7}=5$ irrigations (skipping two irrigations at flowering and pod filling stages), $\mathrm{l}_{8}=4$ irrigations (skipping three irrigations at vegetative, flowering and pod filling stages).

irrigations till harvest) $\left(3015.8 \mathrm{~kg} \mathrm{ha}^{-1}\right)$.

It is clear from data listed in Table 5 that the seed yields for irrigation treatments $I_{5}, I_{6}, I_{7}$ and $I_{8}$ were 27.85 , $29.86,19.50$ and $68.60 \%$, respectively, less than that for $\mathrm{I}_{3}$. There was no statistically significant difference between $I_{2}, I_{3}$ and $I_{4}$ for seed yield and might be obtained due to availability of enough moisture at critical stages vegetative, flowering and pod filling. In general, applying treatments $I_{2}, I_{3}$ and $I_{4}$ (skipping one irrigation) were increased the seed yield by $12.12,13.52$ and $2.54 \%$ and water saved by $14 \%$ compared with treatment $I_{1}$ (seven irrigations till harvest), receptively. Results in Table 5 also implied that saving about $42 \%$ compared with treatment $\mathrm{I}_{1}$ (control), saving in irrigation water average over the two growing seasons, could reduce soybean seed yield by an average of $48.51 \%$ over the two growing seasons. Reduction in crop yield as a result of water stress has also been reported for soybean (Desclaux et al., 2000; Behtari and Abadiyan, 2009; Kobraee et al., 2011; Masoumi et al., 2011).

It may be concluded that maximum seed yield would be obtained when crop was grown under skipping one irrigation regimes at flowering stage (six irrigations till harvest). This could be attributed to the fact that increasing available soil moisture during vegetative and reproductive growth of soybean plants increases yield and its components (Gardner et al., 1985). These findings are in agreement with those reported earlier by Kadhem et al. (1985) which applied irrigation at seven different growth stages and reported that seed yield increased when irrigation was applied regularly up to pod filling stage. Ansart et al. (2000) who found that six irrigations applied at different growth stages gave the maximum seed yield, which was associated with better growth and yield components. Shortening of grain-filling period due to water stress (Frederick et al., 2001) and decrease of transferring assimilates into grains due to drought stress as two major reasons for reduction of soybean grain weight. Oya et al. (2004) reported that drought stress is one of the main constraints for soybean production in Brazil and water stress at any stage of soybean development can reduce yield, but the negative effects of water stress are particularly important during flowering, seed set and seed filing.

\section{Oil yield $\left(\mathrm{kg} \mathrm{ha}^{-1}\right)$}

Oil yield per unit area is the ultimate target in growing high-oil soybean genotypes and it is in direct dependence of seed yield and oil concentration. It is a complex character determined by genetic and environmental factors, as well as by their interaction.

Results of ANOVA revealed that oil yield was significantly impacted with irrigation regimes, cultivars and their interactions at $1 \%$ probability level (Table 4). Data regarding oil yield of soybean as affected by different levels of irrigation are presented in Table 5, which indicate that different levels of irrigation had highly significant effect on the parameter under study. Means comparison for oil yield at different irrigation treatments showed that the decrease in irrigation level resulted in the loss of this trait. Oil yield averaged over 2 years showed that the maximum oil yield $\left(685.85 \mathrm{~kg} \mathrm{ha}^{-1}\right)$ was recorded in $\mathrm{I}_{3}$ treatment (six irrigations till harvest), where skipping one irrigation at flowering stage. It was however, statistically at par with treatments $I_{2}$ and $I_{4}$ where skipping one irrigation at vegetative stage and pod filling stage, respectively, While treatment $\left(I_{8}\right)$ show the lowest oil yield $\left(404.26 \mathrm{~kg} \mathrm{ha}^{-1}\right)$.

Severe water regime (skipping three irrigations) reduced oil yield by $41.05 \%$ compared to optimum 
irrigation condition $\left(I_{3}\right)$. The reason for reduction of oil yield with increasing severe water regime was reducing seed yield and oil percentage due to water deficit (Table 5 ). These results confirmed results of Naderi et al. (2005). According to the reducing of yield in water regime conditions in addition as oil yield is depended to the seed yield, we observed reduction oil yield by the seed yield reduction, thus, sufficient irrigation is useful to increase the seed and oil yield (Roshdi et al., 2006).

\section{Protein yield $\left(\mathrm{kg} \mathrm{ha}^{-1}\right)$}

According to ANOVA (Table 4), irrigation regimes affected significantly protein yield $(P \leq 0.01)$. The means of the eight irrigation treatments were compared to study the significant differences among the treatments (Table 5 ). According to the Duncan multiple range test, the results suggested that the highest $\left(1358.82 \mathrm{~kg} \mathrm{~h}^{-1}\right)$ and the lowest $\left(835.59 \mathrm{~kg} \mathrm{ha}^{-1}\right)$ protein yield belonged to $\mathrm{I}_{3}$ and $I_{8}$, respectively. In addition, data indicated that the group of treatments, which received six irrigations $\left(I_{2}, I_{3}\right.$ and $\mathrm{I}_{4}$ ) during three stages, did not show significant protein yield differences among themselves, while showing a significant protein yield advantage over the group, which received four, five and seven irrigations.

Data (Table 5) revealed that highest protein yield $\left(1358.82 \mathrm{~kg} \mathrm{ha}^{-1}\right)$ was produced under $\mathrm{I}_{3}$ treatment which, on an average, was 20.46, 21.29, 21.53 and $38.50 \%$ higher than protein yield produced under $I_{5}, I_{6}, I_{7}$ and $I_{8}$ treatments, respectively. The extents of these reductions were related to the variations in seed yield of soybean under different irrigation regimes. This result is in general agreement with the results reported by Cober and Voldeng (2000) and Behtari and Abadiyan (2009).

In general, it was observed that among various irrigation regimes (Table 5), maximum seed yield (3423.6 $\mathrm{kg} \mathrm{ha}^{-1}$ ), oil yield $\left(685.85 \mathrm{~kg} \mathrm{ha}^{-1}\right)$, and protein yield ( $1358.82 \mathrm{~kg} \mathrm{ha}^{-1}$ ), was noted when crop was grown under skipping one irrigation regimes at flowering stage, whereas minimum seed protein content $(37.24 \%)$ was recorded when crop was irrigated normally. The minimum values of above parameters were recorded, when crop was skipped three irrigations at vegetative, flowering and pod filling stage. Therefore, results showed that with $14 \%$ water saving may be could produce maximum seed, oil and protein yields.

\section{Performance of quality parameters}

Protein and oil concentration are controlled by quantitative genetic factors but it is highly influenced by the cultivation conditions mainly during the grain filling stage. As expected, the protein content has revealed an inverse relationship with the oil content (increased protein content corresponds to decreased oil content).
Given that the protein content in soybean seeds is usually nearly double the oil content, it is apparent that oil is relatively more sensitive to moisture stress (Rose, 1988). Latifi (1989) also determined that increased protein and decreased oil of soybean were associated with irrigation at early pod set and seed filling in Nebraska. Our results revealed that oil percentage was decreased, but protein percentage was increased by decreasing water availability (Table 5). Similar results were reported by Ghassemi-Golezani and FarshbafJafari (2012). In average, optimum protein and oil content of soybean seed should be 20 and $35 \%$, respectively (Henry, 2010). In our experiments, all treatments showed protein values above the $35 \%$ level and oil contents higher than $20 \%$ level, except $I_{5}, I_{6}, I_{7}$ and $I_{8}$ (Table 5).

\section{Seed oil content (\%)}

Statistical analysis of the data (Table 4) revealed that irrigation regimes and cultivars had a significant effect on oil content but their interaction was non-significant. The results in Table 5 showed that significant suppressive effect on oil content percentage by different levels of irrigation. Among treatment means of skipping irrigation, the maximum oil contents $(21.50 \%)$ were found in $I_{1}$ (control) where normal irrigation was applied and it was statistically at par with the treatments $I_{2}, I_{3}, I_{4}, I_{5}$ and $I_{6}$. Therefore, with attention to this study can declare optimum irrigation had more time for filling grain so oil percentage was more in this treatment. The $\mathrm{I}_{8}$ treatment (skipping three irrigations at vegetative, flowering and pod filling stages), gave significantly the lowest oil content $(17.07 \%)$. In general, the oil content declined gradually as the irrigation regimes were reduced from $I_{1}$ to $I_{8}$.

This result is in general agreement with those obtained by Kirnak et al. (2010). In addition, drought stress may be increase the grain husk thickness and reduce grain kernel percentage to grain whole consequently oil percentage decreased. Reduction of the grain oil percentage due to water deficit has also been reported in soybean (Ghassemi-Golezani and Farshbaf-Jafari, 2012).

\section{Seed protein content (\%)}

Based on the results obtained, irrigation regimes have significant effects $(P \leq 0.05)$ on the protein content (Table 4). The comparison of treatment means given in Table 5 reflects that the maximum protein content $(41.15 \%)$ was recorded in $I_{8}$ (skipping three irrigations at vegetative, flowering and pod filling stages) treatment which was statistically at par with $I_{6}$ and $I_{7}$ treatments. Seed protein content $(41.15 \%)$ was significantly higher 
Table 6. Summary of simple linear regression analysis of important relationships of irrigation regimes and seed, oil and protein yield.

\begin{tabular}{lccc}
\hline Dependent variable $(\mathbf{y})$ & $\begin{array}{c}\text { Regression } \\
\text { equation }\end{array}$ & $\begin{array}{c}\text { Coefficient of correlation } \\
(\mathbf{R})\end{array}$ & $\begin{array}{c}\text { Coefficient of determination } \\
\left(\mathbf{R}^{2}\right)\end{array}$ \\
\hline Seed yield $\left(\mathrm{kg} \mathrm{ha}^{-1}\right)$ & $\mathrm{Y}=2976-258.9 \mathrm{x}$ & $-0.78^{*}$ & 0.62 \\
Oil yield $\left(\mathrm{kg} \mathrm{ha}^{-1}\right)$ & $\mathrm{Y}=568.1-50.55 \mathrm{x}$ & $-0.73^{*}$ & 0.54 \\
Protein yield $\left(\mathrm{kg} \mathrm{ha}^{-1}\right)$ & $\mathrm{Y}=1187-96.96 \mathrm{x}$ & $-0.80^{\star *}$ & 0.64 \\
\hline
\end{tabular}

${ }^{* *}$; means that $r$ is significant at $p<0.01$ level of probability.

when crop was grown under skipping three irrigation regimes than seed protein content $(37.24 \%)$ in control, when crop was given normal irrigations, and seed protein content (39.22, 39.69 and $39.61 \%)$, when crop was grown under skipping one irrigation regimes at vegetative, flowering and pod filling stage, respectively. It seems that the water regime forced the plant metabolism to increase the protein synthesis in seeds. Increasing seed protein percentage under water stress was also reported in soybean (Ghassemi-Golezani and FarshbafJafari, 2012) and chickpea (Behboudian et al., 2001).

With attention to correlation coefficients (Table 8), results showed that oil content had significant and negative correlation at $1 \%$ with protein content $(r=-$ $0.661^{* *}$ ). Leffel and Rhodes (1993) also reported that high-protein lines were inferior for seed yield and oil concentration. The inverse relationship between total oil and protein content in soybean is well documented. Schwender et al. (2003) studied the relationship between oil and protein content and suggested that $1 \%$ reduction in total oil content will lead to a $2 \%$ increase in total protein content. Thus, the regulation of carbon flux during embryogenesis will be shifted toward one or the other, which is impacted by both genetics and environment, although strong metabolic links between oil and storage protein synthesis are not apparent. Kumar et al. (2006), Malik et al. (2007) and Kirnak et al. (2010) have also reported a similar negative correlation.

\section{Prediction of soybean seed, oil and protein yield under different irrigation regimes}

Testing the model under the deducting 14, 28 and $42 \%$ of total irrigation could help in scheduling deficit irrigation through avoiding sensitive growth stages to water stress and reduce yield losses. The relationship between irrigation regimes $(x)$ and the different soybean factors (y) was significant at the 0.01 and 0.05 level of significance (Table 6).

Regression analysis showed that there was an inverse linear relationship between water regimes and each of seed, oil and protein yields (Table 6). The assessed variables showed linear response in relation to the water regimes. It can be noticed generally from Table 6 that oil and protein yields were decreased linearly with decreasing water regimes. Therefore, reduction in oil and protein yields per unit area with increasing the severity of water stress could be attributed to sharp decline in seed yield per unit area under water regime conditions. This is indicative of the fact that oil and protein yield is more affected by seed yield than seed oil and protein content. This result is in general agreement with the results reported by Cober and Voldeng (2000) and Behtari and Abadiyan, 2009.

Analysis of regression indicated that a best described response as a linear regression for seed yield and irrigation regimes (seed yield $=2976-258.9 x, R^{2}=0.62$; $p \leq 0.05$ ), oil yield and irrigation regimes (oil yield $=568.1$ - 50.55x, $\left.R^{2}=0.54 ; p \leq 0.05\right)$, protein yield and irrigation regimes (protein yield $=1187-96.96 x, R^{2}=0.64 ; p \leq$ 0.01). Significant linear relationship between water regimes and each of seed, oil and protein yields provides the clue that these traits are dependent upon water regimes.

From the above-mentioned results, it could be concluded that the coefficients of determination $\left(R^{2}\right)$ of $0.62,0.54$ and 0.64 indicated that the irrigation regimes involved in this study affected the total variability of seed, oil and protein yield by 62,54 and $64 \%$, respectively.

\section{Effect of soybean cultivars}

Results from the combined ANOVA (Table 4) showed that highly significant difference existing among all cultivars in term of all traits measured; thus, indicating that there is variability in cultivars studied. The difference in the results might be due to the difference in genetic constitution of breeding material and environmental condition. This result implied that this population of soybean cultivars would respond positively to selection. Abd-Alla and Omran (2002) recorded that soybean cultivars had wide range of variation in growth and yield as well as its attributes. The results of present study are in line with those of Arshad et al. (2006), Zafar et al. (2008), lqbal et al. (2010) and Sharief et al. (2010) who observed a wide range of variability for traits under study.

Results of the comparison of cultivars means presented in Table 7 showed that maximum seed yield was recorded in Giza $111\left(3220.1 \mathrm{~kg} \mathrm{ha}^{-1}\right)$. However, it was found statistically at par with Giza 21 (3016 kg ha') 
Table 7. Mean performance of the studied soybean traits (combined data across two seasons).

\begin{tabular}{|c|c|c|c|c|c|c|c|c|c|c|c|}
\hline Cultivar & $\begin{array}{l}\text { Plant height } \\
\text { (cm) }\end{array}$ & $\begin{array}{c}\text { No. of } \\
\text { branches plant }^{-1}\end{array}$ & $\begin{array}{c}\text { No. of pods } \\
\text { plant }^{-1}\end{array}$ & $\begin{array}{l}\text { No. of seeds } \\
\text { plant }{ }^{-1}\end{array}$ & $\begin{array}{c}\text { Seed } \\
\text { index }(\mathrm{g})\end{array}$ & $\begin{array}{l}\text { Seed yield } \\
\text { plant }^{-1}(g)\end{array}$ & $\begin{array}{c}\text { Oil content } \\
(\%)\end{array}$ & $\begin{array}{c}\text { Protein content } \\
(\%)\end{array}$ & $\begin{array}{l}\text { Oil yield } \\
\left(\mathrm{kg} \mathrm{ha}^{-1}\right)\end{array}$ & $\begin{array}{c}\text { Protein } \\
\text { yield (kg ha-1) }\end{array}$ & $\begin{array}{c}\text { Seed yield } \\
\left(\mathrm{kg} \mathrm{ha}^{-1}\right)\end{array}$ \\
\hline Giza 21 & $111.50^{a}$ & $3.01^{a}$ & $62.38^{a}$ & $115.69 a$ & $14.33^{a}$ & $16.10^{a}$ & $21.72^{b}$ & $38.25^{c}$ & $655.07^{a b}$ & $1153.85^{\mathrm{ab}}$ & $3016.0^{a}$ \\
\hline Giza 35 & $100.54^{b}$ & $2.59^{b}$ & $61.21^{a}$ & $107.67^{a}$ & $12.78^{c}$ & $13.70^{\mathrm{ab}}$ & $17.61^{d}$ & $40.32^{a}$ & $524.26^{c}$ & $1200.92^{\mathrm{a}}$ & $2976.5^{a}$ \\
\hline Giza 82 & $102.04^{b}$ & $2.28^{b}$ & $47.42^{b}$ & $83.52^{b}$ & $14.54^{a}$ & $12.07^{c}$ & $22.99^{a}$ & $38.45^{c}$ & $611.58^{b}$ & $1022.34^{c}$ & $2658.9^{b}$ \\
\hline Giza 83 & $100.25^{b}$ & $2.68^{b}$ & $49.96^{b}$ & $85.17^{b}$ & $12.20^{c}$ & $10.41^{c}$ & $21.57^{b}$ & $39.44^{a b}$ & $616.67^{b}$ & $1127.35^{b}$ & $2857.9^{b}$ \\
\hline Giza 111 & $108.38^{a}$ & $3.21^{a}$ & $67.44^{a}$ & $123.65^{a}$ & $13.22^{b}$ & $16.21^{a}$ & $22.90^{\mathrm{a}}$ & $39.12^{\mathrm{ab}}$ & $737.72^{\mathrm{a}}$ & $1295.76^{a}$ & $3220.1^{a}$ \\
\hline Crawford & $91.46^{c}$ & $2.65^{b}$ & $52.27^{b}$ & $91.48^{b}$ & $13.81^{b}$ & $12.26^{c}$ & $18.80^{c}$ & $38.56^{c}$ & $442.49^{d}$ & $906.97^{d}$ & $2351.6^{c}$ \\
\hline
\end{tabular}

Means followed by common letters are not significantly different from each other according to Duncan's multiple range test (DMRT).

Table 8. Simple correlation coefficients among seed yield ha ${ }^{-1}$ and its related characters in soybean (combined over two seasons).

\begin{tabular}{|c|c|c|c|c|c|c|c|c|c|}
\hline Character & $\mathbf{X}_{1}$ & $X_{2}$ & $\mathbf{X}_{3}$ & $\mathrm{X}_{4}$ & $X_{5}$ & $X_{6}$ & $\mathbf{X}_{7}$ & $\mathrm{X}_{8}$ & $y$ \\
\hline Plant height $\left(\mathrm{x}_{1}\right)$ & 1 & & & & & & & & \\
\hline No. of branches plant ${ }^{-1}\left(x_{2}\right)$ & 0.195 & 1 & & & & & & & \\
\hline No. of pods plant ${ }^{-1}\left(x_{3}\right)$ & $0.563^{\star *}$ & $0.577^{\star *}$ & 1 & & & & & & \\
\hline No. of seeds pod ${ }^{-1}\left(x_{4}\right)$ & $0.542^{\star *}$ & $0.491^{*}$ & 0.489 & 1 & & & & & \\
\hline 1000 -seed weight $\left(x_{5}\right)$ & -0.066 & $-0.423^{*}$ & $-0.596^{*}$ & $0.533^{\star}$ & 1 & & & & \\
\hline Seed yield plant ${ }^{-1}\left(x_{6}\right)$ & $0.540^{\star *}$ & $0.658^{\star *}$ & $0.620^{* *}$ & $0.656^{\star *}$ & $0.703^{\star *}$ & 1 & & & \\
\hline Oil content \% $\left(x_{7}\right)$ & -0.112 & -0.116 & 0.244 & 0.147 & $-0.526^{*}$ & -0.175 & 1 & & \\
\hline Protein content \% $\left(x_{8}\right)$ & -0.141 & -0.119 & 0.117 & -0.165 & $-0.475^{*}$ & 0.217 & $-0.661^{\star *}$ & 1 & \\
\hline Seed yield $\left(\mathrm{kg} \mathrm{ha}^{-1}\right)(\mathrm{y})$ & 0.345 & $0.676^{* *}$ & $0.845^{\star *}$ & $0.811^{* *}$ & $0.741^{* *}$ & $0.615^{\star *}$ & $-0.426^{*}$ & $-0.399^{*}$ & 1 \\
\hline
\end{tabular}

**, *, ns: Significant at 1 and $5 \%$ probability levels and non-significant, respectively.

and Giza 35 ( $2976.5 \mathrm{~kg} \mathrm{ha}^{-1}$ ) followed by Giza 82 $\left(2658.9 \mathrm{~kg} \mathrm{ha}^{-1}\right)$ and Giza $83\left(2857.9 \mathrm{~kg} \mathrm{ha}^{-1}\right)$. Crawford revealed the lowest seed yield (2351.6 $\left.\mathrm{kg} \mathrm{ha}^{-1}\right)$. The difference in seed yield may be due to genetic nature of different cultivars. Giza 111 cultivar surpassed Giza 82 cultivar by $17.42 \%$, Giza 83 cultivar by $11.24 \%$ and Crawford cultivar by $26.97 \%$ in seed yield $\mathrm{ha}^{-1}$. This was expected since it ranked the top in number of branches plant ${ }^{-1}$, number of pods plant ${ }^{-1}$, number of seeds plant $^{-1}$ and seed yield plant ${ }^{-1}$ (Table 7).

The seed yield is the interaction of many factors such as number of branches plant ${ }^{-1}$, number of pods plant ${ }^{-1}$, number of seeds plant ${ }^{-1}$, seed index and seed yield plant $^{-1}$. So on account of those data Giza 111 gave the maximum seed yield. Hussein et al. (2006) found that soybean Giza 21 cv. surpassed Giza 22 and Giza 111 cultivars in 100 -seed weight $(\mathrm{g})$ and seed yield $\left(\mathrm{t} \mathrm{ha}^{-1}\right)$ by 64 and $15 \%$ in the first season and 26 and $12.8 \%$ in the second season, respectively. In addition, Kandil et al. (2012) found that soybean cultivars showed high difference in seed yield and its component, Giza 21 cultivar exhibited maximum number of pods plant ${ }^{-1}, 100$ seed weight and seed yield. Other workers have reported significant yield differences among soybean genotypes (Malik et al., 2007; Rahman et al., 2011; El-Badawy and Mehasen, 2012).

It was also observed that there was great variability among cultivars regarding to their oil and protein yields. In general, it can be concluded that in soybean cultivars, oil and protein yields are positively related with seed yield per unit area. It was obvious that Giza 111 and Giza 21 had highest seed, oil and protein yields in $\mathrm{kg} \mathrm{ha}^{-1}$ as 
compared with the other tested cultivars. The results indicated that Giza 111 cultivar exceeded by $40.0 \%$ over Crawford cultivar and $28.91 \%$ over Giza 35 cultivar of oil yield $\mathrm{kg} \mathrm{ha}^{-1}$. Among different cultivars, Giza 111 better than the other cultivars and Crawford was weakness. Ghassemi-Golezani and Farshbaf-Jafari (2012) reported that oil and protein yields per unit area had significant positive correlation with seed yield per unit area. Giza 111 proved to be the best cultivar followed by Giza 21 among the six cultivars included in the test under different water regime.

Significant yield components differences were observed among the cultivars as average over two years. Statistical analysis of the data also revealed that cultivar had a significant effect on the number of branches plant ${ }^{-1}$ (Table 7). Results showed that the highest of number of branches plant $^{-1}$ was achieved in Giza 111 and lowest number of branches plant ${ }^{-1}$ related to Giza 82 (Table 7). Also, the results indicated that plants of Giza 111 and Giza 21 cultivars were taller than the other cultivars. Data regarding to the number of pods plant $^{-1}$ revealed a significant difference among soybean cultivars (Table 7). Results suggested that the cultivar Giza 111 produced the highest number of pods plant ${ }^{-1}$ (67.44). It was statistically at par with cultivars Giza 21 (62.38) which were statistically at par with Giza 35 (61.21). The lowest number of pods plant ${ }^{-1}$ was produced by Giza 82 (47.42) but it was statistically at par with cultivar Crawford (52.27). The difference in number of pods plant ${ }^{-1}$ can be attributed to differences in genetic makeup of the cultivars. El-Harty et al. (2010) had also reported the significant differences among cultivars for number of pods plant ${ }^{-1}$. The average of both seasons showed that Giza 111 cultivar surpassed Crawford cultivar by $26.01 \%$, Giza 82 cultivar by $32.45 \%$ and Giza 83 cultivar by $31.12 \%$ in seed number per plant. Giza 111 cultivar increased by $24.36 \%$ over Crawford cultivar by $35.78 \%$ over Giza 83 cultivar and $25.53 \%$ over Giza 82 cultivar in seed yield plant ${ }^{-1}$.

With respect to seed quality, data presented in Table 4 indicated significant differences among cultivars in oil contents of seeds under different levels of water regime treatments. A range of $22.99 \%$ (Giza 82 ) to $17.61 \%$ (Giza 35) was recorded for oil content. Similar variability for oil content was also reported by Ramteke et al. (2010) and Malik and Ashraf (2006). ANOVA for protein content revealed that varietal differences were highly significant. In the present investigation, highest protein content was observed in Giza 35 (40.32\%) and lowest in Giza $21(38.25 \%)$ with mean protein content of $39.28 \%$. These observations were found consistent with those of Narne et al. (2002) who reported the range of protein from 27.31 to $41.35 \%$.

It could be recommended that the cultivar Giza 111 and Giza 21 could be used in breeding program for drought tolerance. Also, the results of study showed that between evaluated cultivars, Giza 111 and Giza 21 cultivar has the best seed and oil yield and other characteristics, thus it can be used as a suitable parent in a hybrid breeding program in future.

\section{Effect of interactions}

It is evident from the statistical analysis of the data that the interactions between the cultivars and water regimes revealed highly significant differences for seed, oil and protein yields $(P \leq 0.01)$, and these interactions indicated that cultivars responded differently at different water regimes (Table 4). Moreover, ANOVA showed that the interaction of water regimes $\times$ cultivars was not significant for oil and protein percentages (Table 4). Many researchers have reported similar results (Aminifar et al., 2012; Kobraee et al., 2011; Kirnak et al., 2010). Results of combined ANOVA (Table 4) showed that the effect of interaction between soybean cultivars and years was statistically significant for seed, oil and proteinyields. This result indicates that the performance of cultivars was not the same from 1 year to another. Also, significant effect of this interaction was detected, revealing that the tested cultivars ranked differently from year to year. Therefore, it could be concluded that environmental effects significantly affected the performance of the present soybean cultivars. These results are in agreement with those obtained by Aslam et al. (2002), Kobraee et al. (2011), El-Badawy and Mehasen (2012).

\section{Correlation analysis}

Seed yield in crops is generally, determined by a number of yield-related characters that are morphological in nature. Adequate knowledge of the relationship that exists between grain yield and yield-related characters is essential for the identification of selection criteria to be used for yield improvement in soybeans. There were some significant associations found among characters studied under irrigation regime conditions (Table 8). The results regarding correlation coefficients given in Table 8 showed that the seed yield was positively and significantly correlated with number of branches plant ${ }^{-1}(r$ $\left.=0.676^{\star *}\right)$, number of pods plant ${ }^{-1}\left(r=0.845^{\star \star}\right)$, number of seed plant $^{-1}\left(r=0.811^{\star *}\right)$, 1000-seed weight $(r=$ $\left.0.741^{* *}\right)$ and seed yield plant ${ }^{-1}\left(r=0.615^{* *}\right)$. A strong correlation of seed yield with these traits indicated that, simultaneous improvement of these traits is possible. These findings indicate that selection for each of number of branches plant ${ }^{-1}$, number of pods plant ${ }^{-1}$, number of seeds plant ${ }^{-1}$ and 1000-seed weight and seed yield plant ${ }_{1}^{1}$ would be accompanied by high yielding ability under such conditions.

The analysis of simple correlation coefficients showed that negative and significant correlations were observed 
between seed yield $\left(\mathrm{kg} \mathrm{ha}^{-1}\right)$ and each of oil content ($\left.0.426^{\star}\right)$, and protein content $\left(-0.540^{\star *}\right)$. Increase in these traits will ultimately decrease the seed yield. Number of pods per plant was positively and significantly correlated with number of branches per plant, whereas number of branches per plant was negatively correlated with 1000seed weight. The 1000-seed weight was negatively correlated with seed oil and protein content. However, the negative association of 1000-seed weight with these characters will become a problem in combining these important characters for high seed yield. These results are comparable to the results reported by various scientists including Machikowa and Laosuwan (2011), Malik et al. (2007), and Arshad et al. (2006).

Our findings were in confirmation with the previous studies carried out by Showkat and Tyagi (2010) who indicated that there was positive and significant correlation between seed yield with number of pods per plant and 100 seed weight. Shiraiwa et al. (2004) declared that pod number and seed number are two major factors, which affect soybean seed yield. Cumudini et al. (2001) found that there is a significant and positive correlation between seed yield and number of seeds per plant, number of seeds per pod and 1000-seed weight. Ojo and Amanze (2001) observed that number of pods plant $^{-1}$, number of branches plant ${ }^{-1}$ and pod weight had positive and significant correlation with yield in tropical soybeans. The last three traits were also reported to have high estimates of heritability and genetic advance to suggest that these traits could be used as good predictors of grain yield through simultaneous improvement and selection.

\section{Stepwise multiple linear regression analysis}

Seed yield is a function of integrated effects of various yield components like plant height, number of branches plant $^{-1}$, number of seeds plant ${ }^{-1}$, oil content (\%), protein content (\%) and 1000-seed weight developed under a particular set of environmental conditions.

The results of stepwise multiple linear regression analysis in soybean under water regime conditions was calculated by considering the seed yield $\left(\mathrm{kg} \mathrm{ha}^{-1}\right)$ as the dependent variable and other characters as the independent variables. Results of regression analysis showed that three attributes, number of branches plant ${ }^{-1}$, number of pods plant ${ }^{-1}$ and number of seeds plant ${ }^{-1}$, explained $78 \%$ of the yield variation under irrigation regimes $\left(\mathrm{R}^{2}=0.78, P\right.$-value $\left.\leq 0.05\right)$. Regression equation under different water regimes conditions was:

$Y=2013.95+24.33 X_{1}+8.877 X_{2}+41.983 X_{3}$

Where $Y$ is seed yield and $X_{1}, X_{2}$ and $X_{3}$ are the number of branches plant ${ }^{-1}$, number of pods plant ${ }^{-1}$ and number of seeds plant ${ }^{-1}$, respectively. This equation shows the role each of yield components in final yield. This regression equation could be used to predict the seed yield of soybean under different water regimes conditions in the field and for selection purposes. Positive regression coefficient of the three variables implies that defining a logical index selection with these variables, with considering their narrow-sense heritability and correlation coefficient with seed yield, might be a good strategy for increasing seed yield in soybean.

These results suggested that improvement of seed yield in soybean is linked with these traits and selection of these characters might have good impact on seed yield. Therefore, these traits are important indicators for estimating and improving seed yield in soybean. The results of this experiment conform to the results of Kobraee and Shamsi (2011). Adeniji (2007) on soybean used stepwise multiple linear regression analysis to study the relationships between seed yield and yield components and found that $96 \%$ of the total variation in seed weight could be explained by variation in pods per plant.

\section{Conclusion}

According to the results obtained, it may be concluded that for obtaining better soybean seed yield, six irrigations at all growth stages are essential under the agro-ecological conditions of Middle Egypt. From these experimental results, it can be concluded that decreasing irrigation level had significantly decreased seed, oil and protein yields. Yield gains in soybean can be achieved by manipulating the timing of skipping irrigation. When water is limited, skipping irrigation at flowering stage (6 irrigations till harvest) would produce significant yield gains as compared to control and skipping two or three irrigations. More importantly, based on these results, the highest gain would be achieved by skipping one irrigation at the flowering stage while the lowest by skipping three irrigations at vegetative, flowering and pod filling stages. Practical recommendations to farmers can be based on the above observations. From the present investigation, it is concluded that the cultivars exhibited a wide range of variability for most of the traits. In addition, the study demonstrated the existence of a high yield variation among soybean cultivars. There is therefore high potential of intra-selection within the cultivar for yield improvement. Some cultivars possessed desirable genes for more than one character and hence could be utilized directly or included in hybridization program. From the results, it was concluded that cultivars Giza 111 and Giza 21 have the best performance for parameters in the test under different irrigation regime and hence recommended as the most suitable commercial soybean cultivars under Middle Egypt conditions at Giza Governorate. Based on simple linear regression models the yield could be predicted under such environments that 
need further testing on large scale. According to the results obtained, it may be concluded that there are three characters, which showed significant contribution towards the final seed yield, are number of branches plant $^{-1}$, number of pods plant ${ }^{-1}$ and number of seeds plant $^{-1}$.

\section{ACKNOWLEDGEMENTS}

The authors acknowledge the reviewers for their helpful comments, suggestions, and corrections for the improvement of this manuscript.

\section{REFERENCES}

A.O.A.C. (2000). Official Methods of Analysis of Association of Official Agricultural Chemists. Washington 25, D.C.: The Association of Official Analytical Chemists.

Abayomi YA (2008). Comparative growth and grain yield responses of early and late soybean maturity groups to induced soil moisture stress at different growth stages. World J. Agric. Sci. 4(1):71-78.

Abd-Alla AA, Omran MM (2002). Response of four soybean genotypes to nitrogen fertilization levels and plant population. Ann. Agric. Sci. Moshtohor 40:93-105.

Adeniji OT (2007). Stepwise regression and path analysis of dry matter accumulation in the vegetative and reproduction parts of soybeans (Glycine max (L) Merr). Agric. J. 2(6):697-701.

Ali A, Tahir M, Nadeem MA, Tanveer A, Asif M, Wasaya A, Jamil -Ur Rehman (2009). Effect of different irrigation management strategies on growth and yield of soybean. Pak. J. Life Soc. Sci. 7(2):181-184.

Aminifar J, Mohsenabadi GH, Biglouei MH, Samiezadeh H (2012). Effect of deficit irrigation on yield, yield components and phenology of soybean cultivars in Rasht region. Int. J. Agric. Sci. 2 (2):185-191.

Ansart AH, Kakar AA,Tareen AB, Barecht AR, Kakar GM (2000). Planting pattern and irrigation level effects on growth, yield components and seed yield of soybean (Glycine $\max$ (L.) Merr.). Pak. J. Agric. Sci. 370 (2):61-64.

Arshad M, Ali N, Ghafoor A (2006). Character correlation and path coefficient in soybean Glycine max (L.) Merrill. Pak. J. Bot. 38:121130.

Aslam M, Khan NA, Mirza MS (2002). Soybean seed yield and its components as affected by different irrigation regimes at different reproductive stages. Pakistan J. Agric. Res. 17(4):309-313.

Bartlett MS (1937). Some Examples of Statistical Methods of Research in Agriculture and Applied Biology. J. Roy. Stat. Soc. Suppl. 4:137185.

Behboudian MH, Ma Q, Turner NC, Palta JA (2001). Reactions of chickpea to water stress: Yield and seed composition. J. Sci. Food Agric. 81:1288-1291.

Behtari B, Abadiyan H (2009). Quality and quantity responses of soybean (Glycine max L.) seeds to water deficit. Conference on International Research on Food security, Natural Resource Management and Rural Development. University of Hamburg.

Cober ER, Voldeng HD (2000). Developing high-protein, high-yield soybean population and lines. Crop Sci. 40:39-42.

Cumudini S, Hume DJ, Chu G (2001). Genetic improvement in short season soybean: I. Dry matter accumulation, partitioning, and leaf area duration. Crop Sci. 41:391-398.

Desclaux D, Huynh TT, Roumet P (2000). Identification of soybean plant characteristic that indicate the timing of drought stress. Crop Sci. 40:716-722.

Draper NR, Smith HH (1998). Applied regression analysis. John Wiley and Sons. Inc. New USA. Pp. 58-72.

Duncan D (1955). Multiple range and multiple "F" test. Biometrics 11:142.

El-Badawy MELM, Mehasen SAS (2012). Correlation and path coefficient analysis for yield and yield components of soybean genotypes under different plant density. Asian J. Crop Sci. 4(4):1-9.

EL-Harty EH, Rizk AMA, Gendy EK, Abd El-Aal HT (2010). Performance of twelve soybean genotypes under four sowing dates at Middle Egypt. Egypt. J. Plant Breed. 14(2):283-293.

FAO (2010). FAO Stat-Agriculture. Food and Agriculture Organization of the United Nations. Available online at httb://www.fao.org/site/408/DesktopDefault. Aspx?pagelD=408.

Fehr WR, Caviness CE, Burmood DT, Pennington JS (1971). Stages of development descriptions of soybeans (Glycine max L. Merrill). Crop Sci. 11:929-931.

Frederick JR, Camp CR, Bauer PJ (2001). Drought stress effects on branches and main stem seed yield and yield components of determinate soybean. Crop Sci. 41:759-763.

Gardner F, Pearce R, Mitchell RL (1985). Physiology of Crop Plants. lowa State University Press, Ames, USA. P. 66.

Ghassemi-Golezani K, Farshbaf-Jafari S (2012). Influence of water deficit on oil and protein accumulation in soybean grains. Inter. J. plant, Anim. Env. Sci. 2(3):46-52.

Golkar P, Arzani A, Rezaei AM (2011). Determining relationships among seed yield, yield components and morpho-phenological traits using multivariate analyses in safflower (Carthamus tinctorious $L$.). Ann. Biol. Res. 2(3):162-169.

Gomez KA, Gomez AA (1984). Statistical Procedures for Agricultural Research. 2nd ed., New York: John Wiley and Sons, Inc. pp. 108116.

Henry T (2010). The department of agriculture's (USDA) grain inspection, packers and stockyards administration (GIPSA) hand book: USDA soybean oil standards. Washington, USA.

Hussein TF, Darweish GA, Rattiba MM (2006). Effect of planting dates on growth yield and quality of some soybean cultivars. J. Agric. Sci. Mansoura Univ. 31:587-594.

lqbal Z, Arshad M, Ashraf M, Naeem R, Malik MF, Wahead A (2010). Genotypic divergence and correlation studies of soybean (Glycine max L. Merrile) genotypes. Pak. J. Bot. 42(2):971-976.

Kadhem FA, Specht JE, Williams JH (1985). Soybean irrigation serials timed during RI to Rs. Agron. J. 77(2):291-298.

Kandil AA, Sharief AE, Morsy AR, El-Sayed MAI (2012). Performance of some promising genotypes of soybean under different planting dates using biplots analysis. J. Basic Appl. Sci. 8:379-385.

Kirda C (2002). Deficit irrigation scheduling based on plant growth stages showing water stress tolerance. Deficit irrigation practices. FAO Corporate Document Repository 22:3-10.

Kirnak H, Dogan E, Turkoglu H (2010). Effect of drip irrigation intensity on soybean seed yield and quality in the semi-arid Harran plain, Turkey. Spanish J. Agric. Res. 8(4):1208-1217.

Kobraee S, Shamsi K (2011). Effect of irrigation regimes on quantitative traits of soybean (Glycine Max L.). Asian J. Exp. Biol. Sci. 2(3):441448

Kobraee S, Shamsi K, Rasekhi B (2011). Soybean production under water deficit condition. Ann. Biol. Res. 2:423-434.

Kranz WL, Elmore RW, Specht JE (1998). Irrigating Soybean. University of Nebraska-Lincoln Extension educational programs.

Kumar V, Rani A, Solanki S, Hussain SM (2006). Influence of growing environment on the biochemical composition and physical characteristics of soybean seed. J. Food Compos Anal. 19:188-195.

Latifi N (1989).Yield and morphological response of soybean to time of irrigation and sowing rate. Diss. Abstr. Intern., 40: 5088-5098.

Leffel RC, Rhodes WK (1993). Agronomic performance and economic value of high-seed protein soybean. J. Prod. Agric. 6(3):365-368.

Machikowa T, Laosuwan P (2011). Path coefficient analysis for yield of early maturing soybean. Songklanakarin J. Sci. Technol. 33(4):365368

Malik MFA, Ashraf M (2006). Utilization of diverse germplasm for soybean yield improvement. Asian J. Plant Sci. 5: 663-667.

Malik MFA, Ashraf M, Qureshi AS, Ghafoor A (2007). Assessment of genetic variability, correlation and path analyses for yield and its components in soybean. Pak. J. Bot. 39(2):405-413.

Masoumi H, Darvish F, Daneshian J, Noor mohammadi GH, Habibi D (2011). Effects of water deficit stress on seed yield and antioxidants content in soybean (Glycine max L.) cultivars. Afr. J. Agric. Res. 6:1209-1218. 
Naderi MR, Noor Mohammadi GH, Majidi A, Darvish F, shirani Rad AM, Madani H (2005). Safflower responses to different summer drought intensity in Isfahan. J. Agron. 3:225-212.

Narne C, Aher RP, Dahat DV, Aher AR (2002). Selection of protein rich genotypes in soybean. Crop Res. 24(1):106-112.

Ojo DK, Amanze CO (2001). Prediction of grain yield through heritability and genetic advance of yield parameters in soybeans. Nig. J. Ecol. 3:10-13.

Oya T, Nepomuceno L, Neumaier N, Farias JRB, Tobita S, Ito O (2004). Drought tolerance characteristics of Brazilian soybean cultivars: Evaluation and characterization of drought tolerance of various Brazilian soybean cultivars in the field. Plant Prod. Sci. 7(2): 129-137.

Rahman MM, Hossain MM, Anwar MP, Juraimi AS (2011). Plant density influence on yield and nutritional quality of soybean seed. Asian J. Plant Sci. 10:125-132.

Ramteke R, Kumar V, Murlidharan P, Agarwal DK (2010). Study on genetic variability and traits interrelationship among released soybean varieties of India [Glycine $\max ($ L.) Merrill]. Electronic J. Plant Breed 1(6):1483-1487.

Rose IA (1988). Effects of moisture stress on the oil and protein components of soybean seeds. Australian J. Agric. Res. 39 (2):163170.

Roshdi M, Abad HHS, Karimi M, Noor Mohammadi GH, Darvish F (2006). Effects of water deficit on yield and yield components of sunflower cultivars. Scientific Agric. Res. 12(1):109-122.

Russell OF (1994). MSTAT-C v.2.1 (a computer based data analysis software). Crop and Soil Science Department, Michigan State University, USA.

Salimi S, Moradi S (2012). Effect the correlation, regression and path analysis in soybean genotypes (Glycine Max L.) under moisture and normal condition. Int. J. Agron. Plant Prod. 3(10):447-454.

Schwender J, Ohlrogge JB, Shachar Hill Y (2003). A flux model of glycolysis and the oxidative pentosephosphate pathway in developing Brassica napus embryos. J. Biol. Chem. 278:2944229453.
Sharief AEM, EI-Kalla SE, Salama AM, Mostafa El (2010). Influence of organic and inorganic fertilization on the productivity of some soybean cultivars. Crop Environ. 1(1):6-12.

Shiraiwa T, Uneo N, Shimada S, Horie T (2004). Correlation between yielding ability and dry matter productivity during initial seed filling stage in various soybean genotypes. Plant Prod. Sci. 7(2):138-142.

Showkat M, Tyagi SD (2010). Correlation and path coefficient analysis of some quantitative traits in soybean (Glycine max L. Merrill.). Res. J. Agric. Sci. 1(2):102-106.

Sendecor GW, Cochran WG (1989). Statistical Methods, Eighth Edition, lowa State University Press.

SPSS Statistics 17.0.0 (2008). SPSS for Windows. SPSS Inc. 2008.

Steel RGD, Torrie JH, Dickey DA (1997). Principles and procedures of statistics: A biometrical approach. McGraw Hill Book International Co., New York.

Zafar I, Arshad M, Ashraf M, Mahmood T, Waheed A (2008). Evaluation of soybean (Glycine max L. Merill) germplasm for some important morphological traits using multivariate analyses. Pak. J. Bot. 40(6):2323-2328. 